\title{
Monitoring of the habitat agenda in Mexico: the local urban observatory
}

\author{
O. Frausto-Martínez ${ }^{1} \&$ M. Welch-Guerra ${ }^{2}$ \\ ${ }^{1}$ Urban Observatory Riviera Maya/University of Quintana Roo, Mexico \\ ${ }^{2}$ Department of Spatial Planning and Spatial Research, \\ Bauhaus University, Weimar, Germany
}

\begin{abstract}
Indicators are regarded as important tools for the implementation of Monitoring of the Agenda habitat in Mexico. Since the beginning of the debate about indicators in 1992 different concepts have been developed. Some of the existing indicator sets have been tested already. The results have led to the conclusion that the indicator concepts of the "first period" need to be improved. One of the most important outcomes of the experiences until now is that it is almost impossible to develop indicators or indicator sets that are suitable for every spatial area or different region. The results of the testing-program of the UN Habitat Mexico confirm this fact. In the present contribution 37 experiences of sustainability indicator development for a specific regional context are presented. The examples from 37 cities underline the necessity of developing indicator concepts based on the specific problems and goals for the region without neglecting the global principles of sustainability. Furthermore, the description of both case studies (methodology of selection, indicators and their application) illustrates the problems and challenges of indicator concepts for a specific region. Finally the author gives some recommendations for the development of sustainability indicators for a specific regional context in Mexico.
\end{abstract}

Keywords: habitat agenda, Mexico, indicators, local urban observatory.

\section{Introduction}

In 1996 the HABITAT II City Summit was convened to consider the status of various issues addressed at United Nations conferences - Rio 92, (UNCED, Environment and Development), Vienna 93 (Human Rights), Cairo 94 
(Population), Copenhagen 95 (Social Development) and Beijing 95 (Women) in the light of today's reality.

These intergovernmental Conferences have fostered broad debate at various levels of government, and in non-governmental organizations (NGO's) and civil society in general, both in the preparation for the conferences themselves, as well as in their actual occurrence, along with other forums in parallel. This has given rise to social movements of reflection, debate and subsequent implementation, as is the case with the Agenda 21 programmes.

The declaration of the Istanbul summit calls for the establishment of HABITAT Agendas in the member states, regions and cities, to establish action plans that offer solutions to its two basic goals: "adequate housing for all" and the "development of sustainable human settlements in an urbanizing world." The declaration places emphasis on the development of effective forms of governance and citizen participation (Giraldo, et al. [1]).

\section{The habitat agenda}

UN-HABITAT has been a pioneering organization in the establishment of urban indicators. In 1991, UN-HABITAT began its Housing Indicators Programme. In 1993 this became the Programme of Urban Indicators with a broader focus on other urban subjects. The programme produced two main databases in 1996 and 2001 (Global Urban Database I and II), that were unveiled at the Habitat II (1996) and Istanbul +5 (2001) conferences.

In the Habitat Agenda (result of the Habitat II Conference, 1996) the Member States of the United Nations and the partners of the Habitat Agenda asked UNHABITAT to continue to monitor urban conditions on a world scale. They also undertook to monitor urban conditions in their own countries and provide regular progress reports.

The Habitat Agenda and the Millennium Development Goals are intimately related, and to monitor the progress of these commitments a system of 23 key indicators has been designed, as well as nine list of minimum qualitative information to provide information on urban development and the habitability conditions of cities. The indicators measure performance and trends in 20 key areas of the Habitat Agenda [2]. The indicators are monitored through local urban observatories, according to López [3]. In 1997 local urban observatories were created with the objective of developing and gathering information, and measuring the progress of the Habitat Agenda indicators.

\section{Urban observatories and habitat development agencies in Mexico}

In April of 2003 an agreement was signed between the government of the United Mexican States through the Secretary of Foreign Relations (Spanish acronym, SRE), and the Regional Office for Latin America and the Caribbean of the United Nations Human Settlements Programme (ROLAC -UN HABITAT), to establish a UN-HABITAT office in Mexico (UN-HABITAT Mexico), to 
collaborate in the consolidation of the Habitat Agenda and promote the creation of Urban Observatories in Mexico [4].

The Secretary for Social Development (Spanish acronym, SEDESOL) designed the Habitat Programme with the objective of coordinating the goals of social policy with those of urban development policy, and began to implement it in 2003. This fact implies the recognition of those who have been left behind, and the profound social contrasts in Mexico's cities and metropolitan areas. As a result, it has been included as an issue for the 2003 - 2006 National Agenda. Furthermore, SEDESOL implements the federal programme of Local Urban Observatories, which seeks in its initial phase to institute a process of urban planning, coordinate citizen participation and apply the Habitat Development Indicators System. These indicators enable the Millennium Development Goals to be monitored.

The Habitat Programme is being applied in 364 cities of the National Urban System, broken down into: 42 metropolitan areas and 322 municipalities and urban concentrations with more than 15,000 inhabitants, where 64.9 million people reside, two thirds of the country's population [5].

The implementation of the Habitat Programme will be supported by the National Network of Urban Observatories (Spanish acronym, RNOUL), in coordination with the UN-Habitat Office in Mexico. RNOUL is the agency that is in charge of synthesizing the raw information gathered by all Local Urban Observatories established in the country. As such, SEDESOL carries out a comprehensive evaluation of urban trends and conditions in the main cities and metropolitan areas of the National Urban System.

Firstly, the National Network of Local Urban Observatories is made up of 37 Observatories (Figure 1) and represents only $10.16 \%$ of the National Urban System. The implementation de the Observatories and the application of the indicators in Mexico did not involve a specific working procedure, it was instead left to the local, municipal and state agencies to develop procedures based on the considerations of the government, the Observatories and the indicators; problems immediately arose that have yet to be resolved.

In parallel to this, Habitat Development Agencies were set up for the purpose of promoting community participation in local decision making. The urban observatories have taken part in the organization of these Agencies as technical resources for consultation and the provision of information for decision making [6]. In Mexico there are 238 Development Agencies, although fewer than $10 \%$ of them are active or functioning (Figure 2). At the local level, analysis and evaluation of information make it possible to meet the specific needs of cities and metropolitan areas through Habitat Development Agencies and the Habitat Fund.

A total of 238 local management units (Habitat Development Agencies) were tallied in Mexico in 2006, of which 128 are city, 97 municipal, 10 metropolitan, 1 state-level, and 2 regional level. Furthermore, of the total, 28 can be found in cities and metropolitan areas located in the coastal areas of the Pacific, the Caribbean and the Gulf of Mexico. On the other hand, of the same total, 40 Agencies can be found in border cities and metropolitan areas, of which 29 are 
178 The Sustainable City V

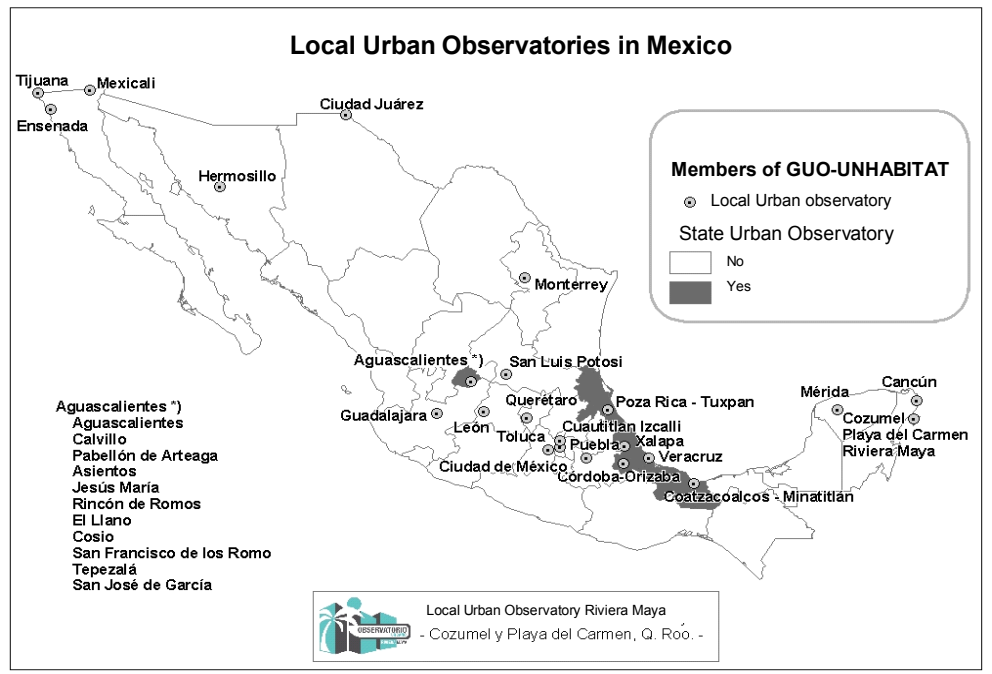

Figure 1: $\quad$ Urban observatories in Mexico (author's rendering).

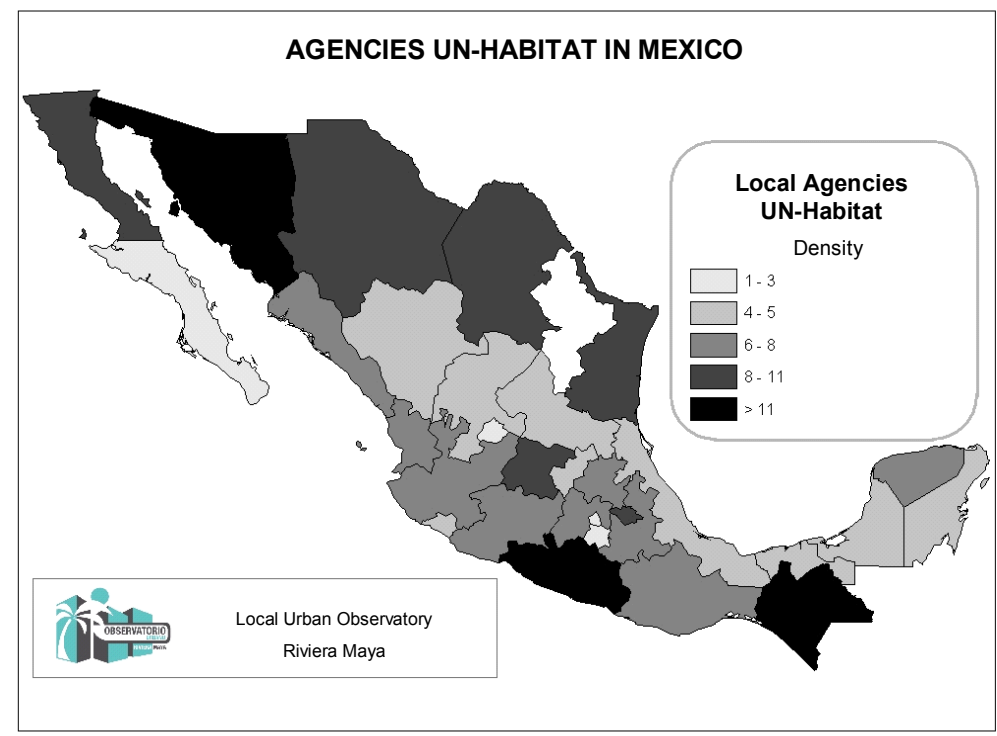

Figure 2: Development Agencies in Mexico by government institution. 
on the northern border and 11 on the southern border. Of the 238 Agencies, 10 are located in national heritage cities.

\section{Discussion}

The implementation of the local urban observatories in Mexico is coordinated by the Office of Urban Development and Territorial Ordinance of the Secretary of Social Development and the Habitat programme of the United Nations, with its representation in Mexico. Thirty seven observatories have been set up and comprise Mexico's National Network of Local Urban Observatories. The first observatories were created three years ago, and positive lessons have been learned, although it is necessary to thoroughly review these in order to guide their conduct, development and relevance.

a) The observatories and their diversification. The observatory has been recognised as a resource for the generation and analysis of key information on a variety of subjects: urban planning, (48 indicators), social violence (39 Indicators), gender (32 indicators), childhood (70 indicators), populations with special abilities (27 indicators), poverty (36 indicators), employment (43 indicators), education (32 indicators), tourism (59 indicators), micro-enterprise (42 indicators), sustainable development (42 indicators), environment (30 indicators), and housing (22 indicators), among others. The generation of more than 300 indicators has given rise to a discussion about proceeding to create subject-oriented observatories without there being a horizontal and transverse linkage. In each one of the observatories indicators have been generated which, in most cases, repeat information. As a result of this, the proposal in this regard is concerned with the development of an INFORMATION SYSTEM OF INDICATORS.

b) Urban observatories and their organization. The definition of an urban observatory clearly indicates the scope and role to be played by the organization. Currently, it has been seen that the observatory is a nonexclusive technical resource of the Habitat Development Agencies, whereas a number of organizations have been identified that support their decisions with the information generated by the observatories. The most notable of these include the Municipal Planning Institute, the Municipal Strategic Plan, the Municipal Council, the Citizens' Consultant Council, the Secretary of Urban Development (environment and Ecology), the Secretaries of Planning and Development, the Regional Development Plan, the Studies Programme of a college, the Research Programme of a University or Research Centre. The indicators and tasks that the Urban Observatory performs should respond directly to the information needs of these organizations, while most of the observatories have focused on providing the UN-Habitat indicators, without a direct identification of the needs of the users of the information. The proposal is based on identifying these needs and establishing them as a basic priority among the tasks to be undertaken for $2008-2011$. 
c) Urban observatories research and study. The observatories have positioned their activities as research and preparation of specific studies required by the community. The provision of indicators for Habitat Agenda in 2005 and their updating for 2006 have served as their point of departure. Specifically, the preparation of the following has been identified: Diagnostics and community development plans at the municipal level (2004, 2005 and 2006), Basic diagnostics and followup to the indicators of social and gender violence (2006 and 2007); Diagnostics on childhood (2006), Territorial reorganization of the Habitat polygons (2004-2006), Risk Atlas (2005 and 2006). In collaboration with NGO's, studies have been performed on specific needs such as: A vision of social problems (2005), a Diagnostic for problems of drug addiction in children and youth (2006) and A vision of the City of Cozumel to 2025. The proposal is to disseminate the methodologies and studies, as well as operating proposals for financing in order to identify sources of funding and replicate studies of local interest.

d) Urban observatories and scales of representation. Seven types of representations have been identified: Habitat polygons (Zones for Priority Attention), Neighbourhoods, Basic Geo-statistical Areas (Spanish acronym, AGEB), city, municipal, state and regional. From the perspective of support for the Habitat programme it is possible to recognize the polygons as the basic unit, though there are problems involved with correlating scales of representation. The main problem is the convention for decision making that is most common: the neighbourhood as a strategic tool for city planning. As represented in studies, and because of the kind of basic information gathered to compile the indicators for the Habitat Agenda, the aim is to make consistent reference to neighbourhoods and not to AGEBs or habitat polygons.

e) Urban Observatories and project financing. The survival of the observatories is based on the role they assume, whether it involves opinion on matters of urban concern (in general the financing of sessions is paid for by municipal authorities, research centres and civic associations); by their role as capacity builder for social actors (the courses, workshops and seminars are financed by SEDESOL, research centres or city government) and as project executor. This last type of task is most subject to financing difficulties because most of the observatories do not have their own independent legal and tax status established. In spite of the offering of tenders for project financing of interest to the observatories, the internal capacities of the members have prevented them from participating in such things as CONACYT, social co-investment, bid solicitations for municipal projects, etc.

f) The observatory and social linkage. Although the observatory has been defined as a technical resource, in most of them there are problems of participation and representativeness. The representatives and managers 
of the observatories need to "get to know the city" they are observing. They should get to know its problems, actively take part in its governing bodies and decision making and recognise the "community notables." Dialogue with this latter group would provide relevant information and could, thus, provide the indicators necessary for decision making. A specific proposal is for the managers to prepare a diagnostic for the actors (social, governmental and business sector actors) who comprise the technical council, highlighting the role of each in the community's activities.

g) The urban observatory and strengthening citizenship. The role of the observatories in strengthening capacities for decision making is clear, and yet it is apparent that the observatories are generating indicators without considering the strengths of the members of the technical and consulting councils they are providing with information, and on this basis they could consider it a central undertaking to see to it that the reports on human development indicators are read and used; the indicators could be used in the city's development policy, and in training for emerging issues such as sustainable development, the millennium development goals, the Habitat programme, the Habitat Agenda, social and gender violence, urban mobility, participatory planning and strategic planning.

\section{Conclusions}

The areas of opportunity for urban observatories have been indicated, above all in the responsibility and working of the National Network of Urban Observatories, which should guide and oversee the achievement of goals and reinforce successful efforts, with the aim of replicating them at the national level.

The main areas of opportunity are centred on the diversity of subjects that have been developed by the observatories in Mexico, the forms of internal organization, the kinds of studies and innovative research on urban subjects, the scales of representation and resolution that allow for comparison at the level of households, city and cities, while the financing of the observatories is a crucial subject for the maintenance of the programme. Finally, the areas of social linkage and strengthening of civil society have been fortified with the implementation of the observatories.

The monitoring of the Habitat Agenda and indicators in Mexico needs to be evaluated in depth with the aim of strengthening the programme of the National Network of Urban Observatories and national commitments up to 2015.

\section{Acknowledgements}

This work was carried out with support provided by SEDESOL-UQROO for the purpose of conducting a Local Urban Observatory seminar on Soil, Territorial 
Ordinance and Geographic Information Systems, offered at Cozumel, Quintana Roo on August 29 to 31, 2007, and also to present progress on the author's doctoral thesis.

\section{References}

[1] Giraldo, F., García, J., Bateman, A. \& Alonso, A. Habitat y Pobreza- Los objetivos de desarrollo del milenio desde la ciudad. ONU-Habitat. Colombia, pp. 19-39, 2006.

[2] Jirón, P. Indicadores urbanos, impactos en la Conferencia de Estambul +5 y sus direcciones futuras, traducción. Boletín INVI, 45 (17), pp. 83-91, 2002.

[3] López Moreno, E. Urbanización y observatorios locales. Ciudades 68, pp. 2 11, 2005.

[4] Frausto, O., Perdigón, T., Rojas, L., Ihl, T., Tapia, A. \& Chale, G. Sistema de información de indicadores UN-Habitat. Ciudades 68, pp. 52-56, 2005.

[5] CONAPO, http://www.conapo.gob.mx/

[6] Frausto, O. Actualización de indicadores de desarrollo humano de Cozumel. UQROO-UN-Habitat. México, pp. 6-11, 2007. 